\title{
Promoting PT. Woodone Integra Indonesia Using a Company Profile
}

\author{
Christina Suhartono \\ English Department, Faculty Of Letters, Petra Christian University \\ Surabaya, East Java, Indonesia \\ E-mail: tjioechristina@yahoo.co.id
}

\begin{abstract}
The company where I did my internship is PT. Woodone Integra Indonesia or WII. WII was established in 2015 as a manufacturer of engineered wooden doors and other wood related products. The main problem WII is facing is their current ineffective company profile to promote its business to potential customers. It fails to communicate the Unique Selling Proposition or USPs of WII in a persuasive way. Additionally, the contents are not up to date and the design is not interesting enough to attract potential customers. This problem led to the inefficient tool usage for the marketing staff on events such as exhibition and clients visit. Thus, the solution to this problem is to replace the current company profile with a newer version. The content of the new tool will be better in terms of content and design as it will highlight the company's USP. The reason it will be a good solution for the company's issue is because the new company profile can be used to attract more potential customers by the marketing staff during said overseas exhibitions and clients visit. Furthermore, it will also benefit WII as it can help the company to introduce and promote not just their company but also their strengths, uniqueness, and credibility to ensure WII stands out from its competitors.
\end{abstract}

Keywords: company profile, promotional tool, wood manufacturer.

\section{INTRODUCTION}

The company where I did my internship is PT. Woodone Integra Indonesia. PT. Woodone Integra Indonesia or WII was established in 2015 as a manufacturer of wooden doors and other wood related products. WII's main office and factory are located on J1. Raya Betro 678, Sedati, Sidoarjo, East Java, Indonesia. Their main product category is Engineering Wooden Doors. WII is the seventh subsidiary of the Integra Group - its parent company. WII has manufactured its product for the domestic market for $20 \%$ while its $80 \%$ is directed to export. Their export target market includes distributors from United Kingdom, Europe, and Australia, while their local target market aims for big projects such as hotels, shopping malls, apartments, and other residential projects from tender of proposal.

During my three and a half - month internship in WII, I found a problem related to business communication. The problem I found in this company is WII's ineffective company profile to introduce and promote its business to potential customers. Their current company profile fails to project WII's strength and uniqueness, or Unique Selling Proposition (USP). Moreover, the content is not up to date and is written in an informative way rather than a more persuasive way. Also, the design of the old company profile is not interesting. These qualities are evident from their low - resolution pictures of their products and their unattractive layout. The company profile booklet they are using right now was made in Microsoft PowerPoint Presentation by the marketing staff. They also only include vision, mission, core values, and numerous pictures. Then, these pictures were not further explained in the form of text; there are only pictures showing the manufacturing factories, the process, the products that were already in stacks, and door sample pictures taken from the Internet.

Furthermore, this problem leads to an ineffective usage of the old company profile when the marketing staff was holding exhibition overseas or having clients visit at WII. Since the information is not up to date, the marketing staff takes a longer time to introduce and promote the company to potential buyer due to additional information. The pictures of the products are also not 
further explained in text, so the company profile is not very clear in terms of serving necessary information for the reader. In addition, the old company profile does not have an actual photo of WII's sample products so whenever customers ask for a picture, the marketing staff has to go to the warehouse first to take the picture with their own phone. Thus, the old company profile becomes an obstacle for the marketing staff to do their job properly.

I decided to choose the inefficient company profile problem as my Business Communication Final Project. Due to the ineffectiveness of their current company profile booklet, I will make a new company profile to overcome this obstacle. A resolution for this issue is important because without a proper company profile, the marketing staff will continue having trouble in doing their most important job: promoting the business to potential international customers. To make sure a company is well known in its industry, they will need a good company profile. Customers will want to know first about the business, its credibility, and its products or services before investing in the company, especially since WII is a manufacturing company that sells its products and services to other businesses such as door distributors. Thus, the new company profile can help the marketing staff to promote WII including its USPs, products, and services more effectively to potential customers. The company profile will not become an obstacle but instead a useful tool in attracting more customers for the company.

The problem of the project is how to promote PT. WoodOne Integra Indonesia to potential and existing customers with a company profile. Therefore, a new company profile booklet is the best solution to replace the current ineffective company profile booklet. This booklet will be in English for WII's international clients. It will work as both an effective and appealing tool to provide information about the company, its products, services, and USPs.

The theories I used in making the company profile are definition of brand, definition of branding, definition of promotion, promotion tools, definition of company profile, purposes of company profile, features of company profile, print, effective business writing, visual hierarchy, and color theory.

\section{METHODS}

In the making of the Business Communication Tool for WII, there were some procedures I have accomplished. Firstly, I gathered all necessary data including information and photos regarding the company from the old company profile, staff interviews, the company's official website, and product catalogue. I arranged all of the information and categorize them into the three main USPs that I got based on the old company profile, staff interview, and the website: vertically integrated system, its reliable production capacity, and its modern manufacturing process. I got the first USP: vertically integrated system, based on WII's main website that stated this unique system to contrast the company itself from the rest of its competitors in Indonesia. Next, the second and third USP: reliable production capacity and modern manufacturing process were concluded from the old company profile and staff interview. Since the old company profile was too informative, I interviewed the marketing staff to gain more information about WII's production capacity and machine and why they are included in the old company profile. Thus, the term 'reliable' on the second USP was created to show its capability to handle big orders because of WII's large manufacturing and storage area. In addition, the term 'modern' on the third USP was created to show its cutting edge technology such as UV Cefla machine in its manufacturing process. Finally, the data is arranged and made into a table contents.

The next step is to consult the table contents to the marketing staff. There were few changes especially on the product photo lists and the omittance of the major clients section because the company already has a Project Reference book. However, the overall content was approved.

After a revised version of the content was submitted and approved, the photo sessions were scheduled and conducted. Following the photo session was the copywriting. I wrote some parts of the company profile such as the 'products guide' and 'modern manufacturing process' and revised the writing of the old company profile to be used in the 'about us', and 'reliable production capacity'. Next, I arranged the content including the pictures and text into a complete company profile and consulted them to my advisor before handing it to WII.

\section{FINDINGS AND DISCUSSIONS}




\section{Description of the Tool, its Users, and its Use}

In this part I will explain three things that describe my product in detail which cover the description of the product itself, its users, and its use. First of all, this is a company profile intended for WII. The company profile will come in the form of a booklet and in English only. The content will include "Vision and Mission", "Core Values", "About Us", USPs, "Products Guide", and "Certifications". The 39 - page company profile booklet will be arranged so the reader will have no trouble finding important messages such as the USPs throughout the book and highlighting the company's key messages.

Secondly, the company profile booklet I made is used for two kinds of customers. The first type of customer is someone is not aware of WII. By reading this company profile, it will help them to know about the company and its products and services provided by the company. The second type of customer is someone who recognizes WII and is interested in doing business together with the company. By reading this company profile booklet, it will help customers to understand the company and its products and/or services. Thus, they can trust the company more and be willing to do business with WII.

Thirdly, I will describe the usage of this company profile. This company profile for WII has three purposes. The first purpose is to capture the attention of the customer. The second purpose is to build WII's credibility. The third purpose is to help promote WII to get more customers. The company can use this booklet when they are at an overseas exhibition or welcoming a client visit at WII's factory. WII's marketing staff can effectively promote the company while also showing the USPs and products.

\section{Rationale of the Tool}

In this Business Communication Final Project, I decided to make a company profile booklet for WII. WII is a company brand that should exist in customers mind (Healey, 2008, p.7). WII has to do branding to make sure customers have a long-lasting and good perception of the brand. Branding is a consistent and continuous effort to build brand awareness and expand customer loyalty (Wheeler, 2013, p.6). However, one of many media to do branding is through promotion. Promotion is "the communication process in the marketing that is used to create a favorable predisposition toward a brand of product or service, an idea, or even a person (Semenik, 2002 , p.7)." Thus, the promotion of WII using a company profile booklet is aiming to assure customers to choose WII over the other competitors. To do promotion, I have decided to use a traditional promotion tool. A traditional media such as printed media still remains prominent until this day (Kokemuller, 2018). Print media consists of "newspaper and magazines, directories, mail, brochures, packaging and all other forms of message delivery that are produced by printing words or images on paper or some other material, such as balloons, t-shirts, caps, and pens" (Duncan, 2005 , p. 348). Thus, to replace the current ineffective company profile, I decided to make the company profile in a printed form such as booklet. Furthermore, print messages are relatively more permanent than a broadcasted message, which means it can be saved and visited anytime easily without an electronic device. A printed piece is also easy to distribute to the customers and carry around by the customers especially during exhibition and clients visit.

First of all, I will explain about the rationale of the content of the company profile. The content includes a "Vision Mission", "Core Values", "About Us", the three USPs, the "Product Guide", and the "Certificate". I did not include "Achievements and Milestones", "Company's Culture", and "Profile of Key Personnel". The reason is because "Achievements and Milestones" will have a different book called "Project Reference". Section "Company's Culture" is not included because the main focus of this company profile is to promote WII towards potential customers, not to recruit employees. Section "Profile of Key Personnel" is not included because the information is not needed, and it will make the new company profile have too much information before the main USPs are presented in the first pages. The general overview and company's history is combined into one section in the "About Us" to make it more concise and compact. This is so that the reader will find it interesting while still gaining important knowledge about the company's introduction. In addition, the order of the content will follow the visual hierarchy theory (Phillips, 2015). Visual hierarchy is the order of importance within a social group (such as the regiments of an army) or in a 
body of text..." The visual cues, such as size, position, arrangement, and color, will be used to create a visual hierarchy. Therefore, I will make sure each title is highlighted with a corresponding picture to convey the key point of the page. Thus, the layout will be organized in such manner: the left page will contain the big title, subtitle, and a picture. The right page will contain the details explaining further about what the title means. This is to ensure the reader finds it easy to spot key points of each page and obtain the information.

Second of all, I will explain the rationale of the design of the company profile. The main colors used are green, white, and brown to symbolize Integra Group's logo. These colors are warm colors (Drew \& Meyer, 2005) to further illustrate a sense of warmth in WII's tagline "a good relationship between wood and humans". A good relationship is associated with warmth, thus the new company profile will only uses warm toned colors. In addition, the color yellow might not be present in Integra Group logo, but is used to add variety in the font color. The color yellow matches nicely with the main color palette because they create a harmonious analogues color, which is a combination of colors that are near its left and right in the color wheel. The color yellow is suitable for texts that have a darker background such in section about us and the USPs. Furthermore, these colors also represent psychological meaning (Hand \& Middleditch, 2013). Green is associated with natural world, at one with the world, therefore it can also resemble WII's main raw material: trees from the company's forests concessions. Yellow is associated with happiness or well being, thus it can also resemble the company's tagline: a good relationship between wood and humans. White is associated with universal balance, therefore it can also resemble WII's responsible resource management that is legal and proven from the certificates. Brown, according to Eiseman, is associated with nature, thus it can also resemble the main color of wood used in the products. Finally, I will explain about the rationale of the changes I have made in the new company profile.

\section{Front and Back Cover of the Company Profile}

In the front cover, I put the picture of Integra Group main building as the front cover to make a good first impression of the company. This cover picture also connects with the rest of the content in the company profile, which is to promote a wood manufacturer company that uses trees as their main raw material. After the company's name, I put "Wood Products Manufacturer" so first time customers can get a general sense of the company's products and services. Furthermore, the tagline is present below to better represent the company's beliefs, thus evoking emotion from the reader.

Next, in the back cover there is WoodOne Integra Indonesia logo along with its contact information such as address, telephone number, website to both companies Woodone and Integra group, and four certification logos. This is to emphasize call to action so potential customer knows where to contact WII to place an order.

\section{Photo of Integra Group front office}

I put the photo of Integra Group main building again in the first page because the picture is not only visually pleasing, but also is presented more fully without any text and other objects to obstruct the view. Thus, customers can fully appreciate the photo and first impression of the company.

\section{Table of Contents}

The new version has table of content to easily guide the customer throughout the company profile booklet. Also, this page will serve as an outline to show what the content of the rest of the book is about.

\section{Our vision and mission}

The vision's and mission's content remains unchanged as it is the key part of the joint company: Woodone. However, I added "our" in the title "Vision and Mission" to make it more personalized. I included vision and mission in the new company profile because it summarizes the company's purpose

\section{Our values}

The section's content remains unchanged as it is the key part of the joint company: Integra Group. However, instead of stating the title "Core Values of Integra Group" I change it to "Our Values" as both companies WoodOne and Integra have joined into one to form WoodOne Integra Indonesia. It is also more personalized and consistent with the previous title. This section is also important so potential customers know the company's personalities and beliefs. 
I also add a corresponding picture to highlight the title. The picture is taken from shutterstock.com, a website that sells royalty-free contents. The picture is used to showcase the values of Integra Group which are integrity, nurture, teamwork, excellence, grateful, responsible, and action.

About Us

This part is crucial since it will serve as an introductory of the company. I based the main message from the old company profile but I reword the language to be more persuasive, professional, and grammatically correct. The old company profile's structure is more stiff and formal, using mostly the format subject, verb, and object. Furthermore, I also mentioned bits of the USP to introduce the reader before explaining it further in the next pages. For example, in paragraph four I mention USP vertical integration system. In paragraph five, I add a hint of USP modern manufacturing process by using the keyword "technology" in the first sentence: "With the synergy between Woodone Corp and Integra Group, PT Woodone Integra Indonesia combines the Internationally acclaimed Japanese Total Production Management system and technology with the rich resources of Indonesia." In paragraph six, I add a hint of USP reliable production capacity by stating company's production capacity that reaches 15,000 doors per month on the last line.

\section{USP 1: Vertically Integrated System}

I changed the title from "Office and Manufacturing Area" to "Vertically Integrated System". In the old company profile, they are explaining how they have a huge land of 27 hectares to manufacture the products in Sidoarjo. In the new one, I changed so "Vertically Integrated System" is explained first. The reason was because this section mentions "competitive prices" which will hook the customers first. Furthermore, I also used a stack of log picture as the background to show the vertical integration system was started from the raw material, the very beginning of manufacturing process. Next, I explained further about how WII's unique vertical integration system allowed them to create the best products with competitive prices and to accept highly customization orders (starting from wood types, cores, complimentary, finishing, veneer, etc) because WII managed the entire process. The unique system is also what makes WII stands out from its competitors as no other company has it. Finally, pictures of the said facilities mentioned in the title are showcased after the text. Each picture is named log yard, saw mill facility, kiln dry, and wood warehouse.

USP 2: Reliable Production Capacity at factory area.

I changed the title from "Log yard, 90 chambers of Kiln Dry and Wood Warehouse" to "Reliable Production Capacity at factory area". The reason for that was because the previous title is just facts, and the information contained in the section was too little because the old company profile only had pictures of the log yard, chambers of kiln dry and wood warehouse. Not to mention these pictures are not named at all, thus lacking necessary information for the reader. Also, the information has not been updated since WII now owns only 64 chambers of kiln dry instead of 90 like in the old company profile.

The new one has the title on the left page and a picture of huge stacks of cut woods ready for manufacturing process and one worker standing near for scale as the background to further imply its big capacity size. I also added an adjective "reliable" to make it more persuasive for the reader. This was because their large manufacturing area of 270,000 sqm will ensure large production capacity being processed well and finished products being stored in their warehouse securely. Thus, any customers who want to place a big order should not worry. Next, I also included a picture from the previous company profile that shows WII's factory area from the sky point of view to further illustrate how big the area is.

\section{USP 3: Modern Manufacturing Process}

I changed the title from "Manufacturing Process" to "Modern Manufacturing Process" with a picture of a working drill drilling into a piece of wood as the background to showcase one of its manufacturing process. In the old company profile, there are only photos of labor work, manufacturing process, and machinery while in the new one I do not just put photos. First I added a brief explanation about WII's modern manufacturing steps that are always up to date with the current standard as well as detail and quality centric. Next, I added pictures of few processes of manufacturing a wooden door: laminating, $\mathrm{CNC}$ machine, Veneering by hot press, and finishing by UV Cefla. These pictures are chosen because they are the machines WII most proud of having to 
showcase their technology. Thus, customers can know that WII has a high standard manufacturing equipment for their products.

\section{Product Guide:}

The old company profile only has a title "External and Internal Doors" then adds various 11 photos taken from the Internet into one page. These pictures are not further explained thus lacking necessary information for customers to know what they are getting from their purchase.

In the new company profile, the title is changed to "Products Guide" because this section will briefly explain about the door components that WII manufactures in which the customer can customize. The picture taken as the background has a context of a beautiful living room with a beautiful white door to relate to the quality of WII's finished products. The picture implies a good finished product that corresponds to the title. This part is important for the new company profile to promote the business further. It includes information about the products that WII sells so customers can immediately contact and invest in the company.

\section{Joinery Range}

Joinery range is a term used to include all door components that makes a door because WII uses a joinery process to manufacture a door. Next, the right page has an illustrated guide of the main components that will be explained further in the following sections. This illustration will make it easy for potential customers to know what type of customization they can have for their order. This section contains "Core types", "Panel, flush, and decorative doors", "Wood Species", "Veneer Grain", "Door frame/door jamb, architrave/casing and skirting", and "Stair parts". All of them will include illustrations and a concise explanation of each section.

Quotes

I added a simple quote relating to a door since WII produces wooden doors. This is to evoke emotion from customers and tell them they have almost reached the ending of the company profile. I choose this quote because it urges reader to trust in WII.

\section{Certifications}

This section serves as the last page of the book to convince customers about WII's credibility. After reading about WII, its uniqueness, and its products, it is best to close it with a firm seal to prove the company's legal credibility. Thus, Indonesian VLegal, GFTN, and FSC certifications are present to confirm WII's legality of forest concession and wood, while ISO 9001:2015 to confirm WII's top quality products and services.

USP 1, 2, and 3 are very important because they will make WII stands out from its competitors by showing its uniqueness and strengths. They give a reason why customers should choose WII over its competitors. Thus, this part is included in the new company profile.

\section{CONCLUSION AND SUGGESTION}


The main problem WII is facing is their current ineffective company profile to promote its business to potential customers. It fails to communicate the Unique Selling Proposition or USPs of WII in a persuasive way. Additionally, the contents are not up to date and the design is not interesting to attract potential customers. This problem led to the inefficient tool usage for the marketing staff on events such as exhibition and clients visit. Thus, the solution to this problem is to replace the current company profile with a newer version. The content of the new company profile is improved in terms of content and design as it will highlight the company's USPs. The USPs highlighted in the new company profile are: vertically integrated system, reliable production capacity, and modern manufacturing process.

The processes leading to the creation of the tool were: first, I needed to make a company proposal, present the proposal, and negotiate the price. After that, I made the concept and script which went through a lot of revisions over the course of the whole process. I did research and interviews in order to get some of the USPs and write the content. Next, I had to be able to communicate my idea to my designer, so the design would project these ideas well. Then, after I obtained all the data I needed including the text and visuals, I arranged the layout and my designer did their work in editing the whole company profile look. Finally, the draft went under couple of revisions under my advisor's guidance to ensure it was the best I could give to the company.

The new company profile is hopefully to be a beneficial tool for the company. The marketing staff can use the new company profile to attract more potential customers during overseas exhibitions and client visits. Furthermore, it will also benefit WII as it can help the company to introduce and promote not just their company but also their strengths, uniqueness, and credibility to ensure WII stands out from its competitors.

My suggestion for the next EBC students who will do a similar project in the future is to allocate their time wisely. They should organize everything in detail, so they can anticipate the unexpected.

\section{BIBLIOGRAPHY}

Di, Hand \& Middleditch, Steve. 2013. Design for Media. England: Pearson Education Limited.

Duncan, Tom. 2005. Principles of Advertising \& IMC. New York: McGraw-Hill/Irwin.

Drew, T. John and Meyer, A. Sarah. 2005. Color Management. London: Quantum Publishing Ltd. Eiseman, Leatrice. 2006. Color: Messages and Meanings. USA, MA: Hand Books Press.

Gladkoff, Michael. 2012. Writing a Company Profile to Build Your Credibility.

Retrieved March 19, 2018, from: https://www.word-nerds.com.au/writing-a-companyprofile/

Healey, Matthew. 2008. What is Branding?. UK, Hove: RotoVision SA.

Kokemuller, Neil. 2018. Marketing Promotional Tools.

Retrieved May 17, 2018, from: http://smallbusiness.chron.com/marketing-promotionaltools-60473.html

Lupton, Ellen \& Phillips, Jennifer Cole. 2015. Graphic Design the New Basic. USA, New York: Princeton Architectural Press.

Miller, Jon \& Muir, David. 2004. The Business of Brands. England: John Wiley \& Sons Ltd.

Opara, Eddie \& Cantwell, John. 2014. Best Practices for Graphic Designer, Color Works. Beverly: Rockport Publishers.

Pack, Poppy. 5 Principles of Effective Hierarchy.

Retrieved April 2, 2018, from: https://www.canva.com/learn/5-principles-effective-visualhierarchy/

Semenik, Richard J. 2002. Promotion and Integrated Marketing Communication. Canada: Dave Shaut.

Wheeler, Alina. 2013. Designing Brand Identity: an Essential Guide for the Whole Branding Team. Canada: John Wiley \& Sons, Inc. 